\title{
PLANNING ENGLISH LANGUAGE CLASSES FROM THE CRITICAL LITERACY PERSPECTIVE: FOCUSING ON RACISM AND SOCIAL ISSUES
}

\author{
Planejando aulas de língua inglesa pela perspectiva do letramento crítico: \\ discutindo racismo e questões sociais
}

Nayara Stefanie Mandarino SILVA Universidade Federal de Sergipe nayaramandarino@hotmail.com https://orcid.org/0000-0002-4713-6242

\begin{abstract}
Considering that English language teaching in public schools requires forming critical citizens (JUCÁ, 2016), this study addresses the work with critical literacy in classrooms. Therefore, my aim is to analyze the process of planning English language classes from the critical literacy perspective (MENEZES DE SOUZA, 2011a; 2011b), focusing on racism and social issues. The three classes lead to writing a personal report, using can, considering the social, historical and political barriers people may face depending on their position within specific time and space.
\end{abstract}

KEYWORDS: Critical Literacy; English Language Teaching; Racism; Social Inequality.

RESUMO: Considerando que o ensino de língua inglesa em escolas públicas requer a formação de cidadãos críticos (JUCÁ, 2016), este estudo está voltado ao trabalho com o letramento crítico nas salas de aula. Meu objetivo é, desse modo, analisar o processo de planejamento de aulas de inglês pela perspectiva do letramento crítico (MENEZES DE SOUZA, 2011a; 2011b), enfatizando o racismo e as questões sociais. As três aulas culminam com a escrita de um relato pessoal, usando can e considerando barreiras sociais, históricas e políticas que pessoas podem enfrentar dependendo de sua posição em determinado tempo e espaço.

PALAVRAS-CHAVE: Letramento Crítico; Ensino de Língua Inglesa; Racismo; Desigualdade Social.

\section{AS A WAY OF BEGINNING}

The so-called traditional pedagogy, as Saviani (2005) explains, emerged in the end of the $19^{\text {th }}$ century, even though its grounding philosophy can be traced back to Antiquity. This concept includes a variety of pedagogical approaches which are based on the 
centrality of teachers and on the transmission of cognitive content, through, amongst other techniques, memorization. This concept, dominant in many phases of the Brazilian education history, can still be observed in some classes. Specifically in language teaching, Lima (2008) claims that many English teachers work from this traditional perspective, considering only grammar rules as content and, consequently, disregarding sociocultural issues. A more recent research shows that the traditional pedagogy is still part of English language classrooms (BOA SORTE; SILVA, 2018). It also highlights that teachers often reproduce disbelief in the effectiveness of language teaching in public schools, a place where the transmission of content would not happen properly due to lack of resources and of background knowledge from students, for instance. Public schools are often referred to by teachers and students as places where learning English is impossible; only in language courses it would be possible (BARCELOS, 2011). However, English teaching in public schools has the goal of contributing to the education of critical citizens, which is why classes should not be focused only on the explanation of grammar structures. As Jucá (2016, p. 4, my translation) puts it, when the language is dealt with as a set of isolated rules, there is a "risk of [...] teaching/learning languages as if they were neutral, that is, as if they did not carry values and ideologies from their communities of use"1.

Planning classes that stimulate critical thinking is a challenging, but not impossible, task. The critical literacy theory - defined as paying attention to and reflecting on how we read the world and on where our interpretations come from (MENEZES DE SOUZA, 2011a) - can help teachers on the process of rethinking their own understandings not only on the concepts of language and learning but also on the ideologies they may reproduce. In this paper, I analyze the process of planning English language classes from the critical literacy perspective, focusing on racism and social issues. The classes were planned in the context of a supervised teaching practicum course I took as an undergraduate student.

\footnotetext{
${ }^{1}$ All translated quotes, from Portuguese to English, in this paper are my responsibility. Original version of the text: "corre-se o risco, nesse caso, de ensinar/aprender línguas como se essas fossem neutras, ou seja, como se não carregassem valores e ideologias de suas comunidades de uso" (JUCÁ, 2016, p. 4).
} 


\section{CRITICAL LITERACY}

The word 'literacy' has been part of studies in Brazil since the 1980s. Throughout time the term has been resignified (JORDÃO, 2013). According to Bezerra (2017), initially, it was understood as the ability to read written texts. Later on, in this decade, the ideological model was theorized; the stream of thought surrounding it sees language as a social practice and acknowledges literacies other than the one addressed in school. Nonetheless, only reading and writing are regarded. In the 1990s, the New London Group gathered scholars who discussed education, considering differences in a globalized world. They questioned the role of schools and proposed the idea of design which refers to meaning making processes that involve different modes, such as images, audios, and spaces. They discuss the so-called multiliteracies. The 'multi' stands both for the many modes which constitute texts and for the infinite social practices that construct and are constructed by texts. Cope and Kalantzis (2009, p. 172) contend that "the multiliteracies approach suggests a pedagogy for active citizenship, centred on learners as agents in their own knowledge processes, capable of contributing their own as well as negotiating the differences between one community and the next." The concept, therefore, goes beyond language, including different modalities and addressing social issues. These studies continue in the 2000s, as Bezerra (2017) explains. Meaning cannot exist isolated from social practices, nor can it be restricted to language. Digital technologies are also considered in the concept of literacy, as well as criticism. The word 'critical' can mean two things, in Janks' words (2014, p. 90):

1. Critical reasoning is used to interpret the meaning of the text, based on an analysis of the choices made by the text maker.

2. In critical literacy or critical visual literacy, the word 'critical' signals an analysis of power, identity and access. The positions on offer in texts are examined in relation to their effects in the world - the interests that are served by the text (JANKS, 2014, p. 90).

In this sense, from the critical literacy perspective, being critical means engaging consciously with a text, considering power relationships, identity and (lack of) access. A text, in any mode(s), serves interests that favor some people while excludes others and should always be seen in relation to the social context where it was and is constructed 
(acknowledging that reading is a process of meaning making in which the reader plays an active role).

Paulo Freire is an important author when it comes to the critical literacy theory. He proposes the idea of wor(l)d, which holds that as we read and name, we construct reality. As Jordão (2011, p. 256, my translation) explains, language is the world because we make sense of it through language. Consequently, "our realities and, therefore, our principles as well as ethical and moral judgments depend on how we see things from the position we occupy in the process." 2 Given that we are part of multiple groups (considering social and economic issues, age, gender, etc.) and take up different positions (student, teacher, mother etc.), our identities are plural and conflicting.

From the critical literacy perspective, language is understood as discourse, which Foucault (1969-2008) relates to power relationships unequally distributed within social practices. He explains that, in addition to power, discourses are validated, that is, accepted as true, depending on the time and space in which they are reverberated. This understanding of power as unequally distributed among people differs from the Marxist one, which holds that power lies in the hands of dominant groups while most people have no power - consider, for instance, one of Freire's early works Pedagogia do Oprimido (1987-1994) where he discusses power as divided between the oppressor and the oppressed. Menezes de Souza (2011a) explains that Freire, in the 1970s, talks about criticism in terms of discovering the ideologies, the truth behind texts in order to stop being manipulated by the author. In the 1980s, Freire defended the multiplicity of truths and put being critical as making efforts to denaturalize and reflect on commonsense. There is a shift of focus from unravelling the author's intentions to questioning one's own understanding and where it comes from (as a social construction). Being critical means listening to ourselves as we listen to others, that is, paying attention to how we understand texts (MENEZES DE SOUZA, 2011a).

By learning to listen, the learner can realize that his [or her] world and word - that is, their values and their meanings - come from the sociohistorical reality in which they were born and to which they belong. The task of critical literacy would be, therefore, to develop this

\footnotetext{
2 "nossas realidades e, portanto, nossos princípios e julgamentos ético-morais dependem de como vemos as coisas a partir das posições que ocupamos no processo" (JORDÃO, 2011, p. 256).
} 
perception and understanding (MENEZES DE SOUZA, 2011b, p. 149, my translation) $)^{3}$.

The author emphasizes that readings, as social constructions, will cause conflict in the sense that the same text can be read differently. Acknowledging the inevitability of difference is crucial in the critical literacy perspective because once we do, we stop considering the different as wrong and start seeing it as another possibility of truth.

From the theory's perspective, in Jordão's words (2013, p. 73, my translation, her emphasis), "language, which exists within social practices, is an ideological space of construction and attribution of meaning that happens in an enunciative process which is always contingent (relative to specific subject, time, and space) ${ }^{4}$." The author highlights the word 'ideological' because ideology is what makes meaning making possible, in other words, we would not be able to construct meanings without our biased positioning. This implies that neutrality is impossible. We need to beware of what we understand because the ideologies, which enable the interpretation process, come from the social; whether we want it or not, we reverberate ideologies. According to Nascimento (2019, p. 967), "language must be seen as bound to social injustices, as injustices can often be performed in and through language, with the use of beliefs, myths, and repertoire toward colonial mastery." As language teachers, we must acknowledge this and plan classes that promote critical literacy and contribute to social justice. There is a significant number of studies which address inequality and colonialism, focusing on issues such as sexism and racism (see BEZERRA, 2019; LÓPEZ-GOPAR; SUGHRUA, 2014; MENEZES DE SOUZA, 2004; PEREIRA; LACERDA, 2019). In this paper, I discuss the process of planning a didactic sequence, from the critical literacy perspective, which deals with social inequality and racism. The latter refers to a system which reinforces and creates inequalities in diverse spheres of life, such as education, based on the concept of race (NASCIMENTO, 2019; SCHUCMAN, 2014).

Milner (2008, p. 332) argues that "race is under-theorized in education." The

\footnotetext{
3 “Ao aprender a escutar, o aprendiz pode perceber que seu mundo e sua palavra - ou seja, seus valores e seus significados - se originam na coletividade sócio-histórica na qual nasceu e a qual pertence. A tarefa de letramento crítico seria então a de desenvolver essa percepção e entendimento" (MENEZES DE SOUZA, 2011 b, p. 149).

4 “a língua, que tem sua existência nas práticas sociais, é um espaço ideológico de construção e atribuição de sentidos, o que se dá num processo enunciativo sempre contingente (relativo a sujeito, tempo e espaço 
author explains that, many times, racism is avoided because the topic makes some people 'uncomfortable', or some understand moments when Black teachers address this issue as the act of promoting their particular interests. These thoughts and actions lead to silence, that is, lack of discussion on the matter which "can leave teacher educators and their students perplexed about what should be covered related to race, where (in what contexts) race can be attended to, and, perhaps most important, how the issue might be explored" (MILNER, 2008, p. 339). As a White person, I keep thinking about how to contribute to social justice, addressing racism in my classes, studies, and decisions, recognizing that I occupy a privileged position in a system which disfavors and harms Black people. I reflect constantly on my own interpretations and choices in order to comprehend what are the ideologies that permeate my readings and their social implications, especially when it comes to planning classes, given that my decisions will have a direct impact on students.

The White identity, as Schucman (2014, p. 84, my translation) explains, is thought of as the norm, in a sense that the 'other' is the one who has a race. Given that, the Critical Whiteness Studies propose studying, exposing, and questioning White privilege. The author explains that "subjects who occupy this position [Whiteness] were systematically privileged on what regards material and symbolic resources, generated initially due to colonialism and imperialism, and which still exist and are preserved in contemporaneity." 5 Questioning and fighting against White privilege have to be done in every sphere of life, involving our individual actions and thoughts, as well as institutional racism.

I am aware that not talking about racism and teaching English based on the idea of a neutral language means reinforcing the dominant ideologies which serve White people's interests while excluding Black people. As Milner (2008, p. 336) explains, all teachers should reflect on how their own practices can promote White privilege, given that "racism is present but not even recognizable because it becomes naturalized and normalized." The practice of (constantly) listening to ourselves as we make sense of the world, in the abovementioned perspective of the critical literacy theory, is a way of perceiving the ideologies we are intentionally or not reinforcing.

\footnotetext{
específicos)" (JORDÃO, 2013, p. 73, destaque da autora).

5 "sujeitos que ocupam esta posição foram sistematicamente privilegiados no que diz respeito ao acesso a recursos materiais e simbólicos, gerados inicialmente pelo colonialismo e pelo imperialismo, e que se mantêm e são preservados na contemporaneidade" (SCHUCMAN, 2014, p. 84).
} 
Within critical studies, there is a theory which addresses the relation between power and race: Critical Race Theory. It holds that racism permeates social, cultural and political spheres and that the neutrality and meritocracy discourses work to maintain White privilege. In this sense, reflecting and deconstructing our understandings on raciality and how it affects people's lives and identities is essential (FERREIRA, 2014; PEREIRA; LACERDA, 2019).

\section{CLASS PLANNING FROM THE CRITICAL LITERACY PERSPECTIVE}

The classes I will discuss henceforth were planned to be developed in a public school where I was an intern, using only materials that were available in the institution (board, textbook, students' notebooks or paper, and colored pencils). The target audience are students in the $6^{\text {th }}$ grade. This is a didactic sequence of three classes and its general objective is to produce, in written form, a personal report of a day in the life of a character, indicating what she or he can (not) do, considering racial and social issues. The specific objectives of the sequence correspond to the general ones of each class separately; they are: to analyze the use of can (not) to describe Francisco Rebolo's painting Futebol (1936), considering racial and social issues; to use the modal verb can in the personal report of a character, considering racial and social issues; to write sentences in accordance with the character's context. Below, I present a diagram that illustrates the organization of objectives. 
Diagram 1: Objectives organization within the didactic sequence

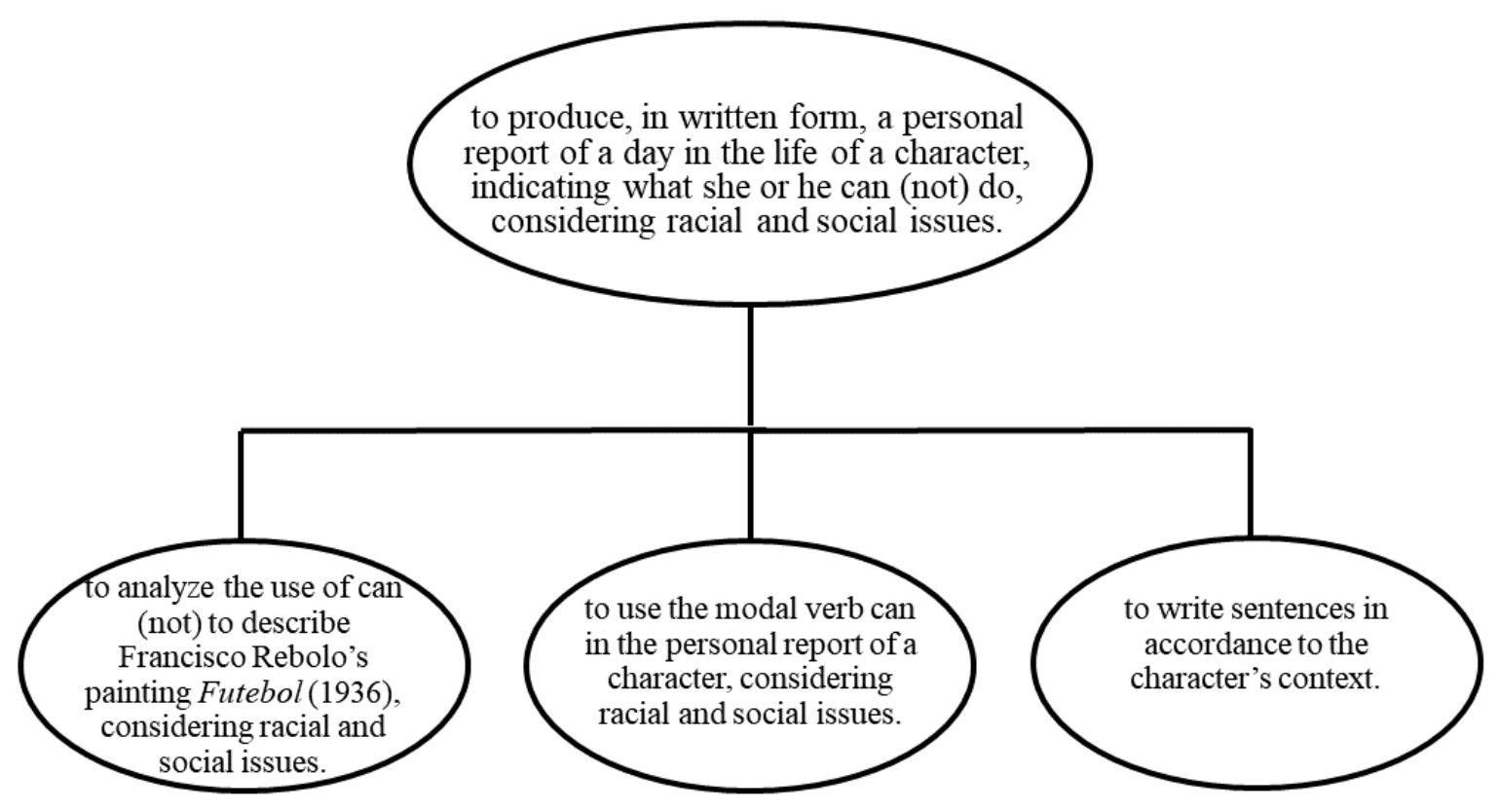

Source: The author (2020).

As Jucá (2016) explains, defining clear goals for classes is an important part of planning, given that one must know what he or she wants to achieve in order to choose the best way to do it. In the context of public schools, the goals include forming critical citizens. Therefore, language should be worked with as inseparable from the social practices that constitute it, considering power relationships and culture, among other issues that permeate social life. In the didactic sequence under analysis in this paper, the objectives were planned to include an aspect of the language (can), the main ability students would work with (writing) and diversity topics (racial and social issues). Recognizing that language is constructed and used within social practices, the classes are organized around a genre (personal report), so the goals are centered in learning how to do something rather than around a grammar topic. Gee (2004, p. 106) criticizes schools' traditional practice of defining learning in terms of content; he calls it 'content fetish'. He contends that

They ask, first and foremost, "What facts and principles - that is, what information - in this domain do I want learners to know?" And then they go on from this point to build their learning environment. But academic domains - the so-called "content" areas of school - are, out in the world, 
not first and foremost "bodies of information." Rather they are things people do with. [...] If you want to design a learning environment, don't start with content, start with the following sorts of questions: "What experiences do I want the learners to have? What simulations do I want them to able to build in their heads? What do I want them to be able to do? What information, tools, and technologies do they need? (GEE, 2004, p. 106).

Considering language classes, specifically, instead of deciding what structures we want students to know, we can ask ourselves what we want to do with language. In these classes, I wanted them to write personal reports, using can critically, reflecting on how being able to do things in society is related to one's position, in this case focusing on racism and social differences.

The first class starts with the following activity: students would draw and paint answers to questions in which can is used; they should keep their drawings because they will be used in the second class. The questions are: "What person can be a boss in a successful company? Who cannot work as a street cleaner? Who can play soccer?". This activity aims to raise students' awareness on their own readings, that is, they will start seeing which groups of people they (unconsciously) associate with certain social positions (boss, soccer player, and street cleaner). Then, in order to emphasize the use of can in the questions, students would discuss "Which word is used in all of the sentences? What does it express? Is it possible to use this word in other situations?". In this sense, grammar is approached inductively, because rather than explaining the rules concerning the use of can, students analyze it in a context (LARSEN-FREEMAN, 2003). Based on discussions, a mind map will be created on the board. After that, in groups, students would analyze Francisco Rebolo's painting Futebol (1936), which is in their textbook along with a short explanation $^{6}$ - in Portuguese - of its context (AGA; MARTÍNEZ, 2015, p. 120), relating it to can.

\footnotetext{
${ }^{6}$ The text describes who Francisco Rebolo is and highlights that in 1936 soccer was an elite sport which only White and rich people could play (AGA; MARTÍNEZ, 2015, p. 120).
} 
Figure 1: Futebol (1936), Francisco Rebolo

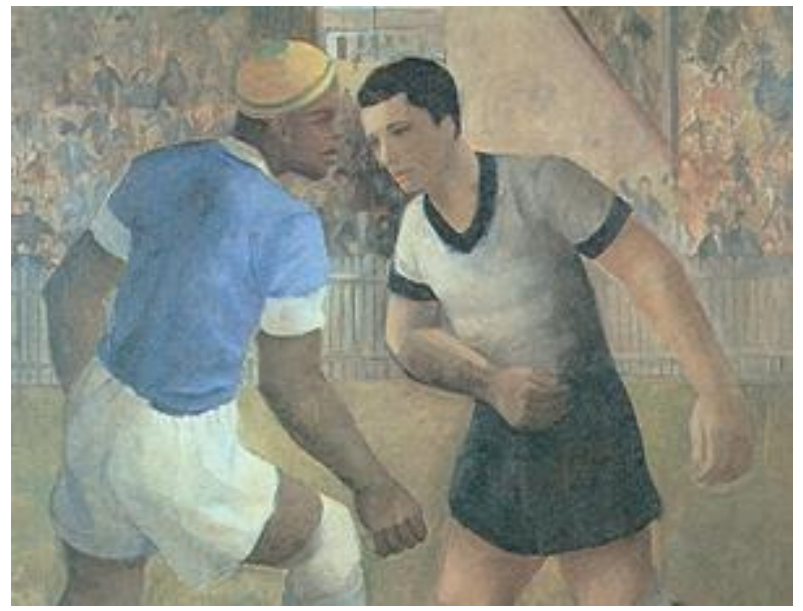

Source: Ribeiro (2010) ${ }^{7}$.

The analysis would be guided with these questions: "Describe the image. What do you see? What is the context in which the painting was made? Was this scene common back then? Is it common now? Consider the uses of the modal verb can and analyze what each sentence expresses: (In 1936) The Black man in the image can play soccer. / The White man in the image can play soccer. / (In 2019) Can you play soccer?" Acknowledging the importance of images in the current concept of literacy (MONTE MÓR, 2008), the starting questions explores the painting, having students discussing what they see so they can realize how their interpretation is related to the elements in the image. The questions also explore the concept of language as "contingent (relative to specific subject, time, and space)" (JORDÃO, 2013, p. 73, my translation) and ideological. Students are asked to consider their own contexts and the paintings' and analyze sentences which aim to highlight that the use of can is not just about its grammar rules, but to context and ideologies.

In the first sentence "(In 1936) The Black man in the image can play soccer", given the time mark, can is used to express permission, as a synonym of being allowed to, because in 1936 only Whites were allowed to play soccer, that is, the Black man was given permission to play soccer, given social rules of the time. The second sentence, on the other hand, "The White man in the image can play soccer" employs the use of can to

\footnotetext{
${ }^{7}$ Available at: <http://globoesporte.globo.com/futebol/times/corinthians/noticia/2010/08/jogador-e-artistacampeao-de-1922-rebolo-desenhou-atual-escudo.html>. Access on: 20 Apr. 2020.
} 
express ability. Considering that in that time it was considered 'natural' to see a White man engaging in this activity, it would not be necessary to talk about permission. This pair of sentences contrasts, within the same time mark (1936), how Black and White could be subjected differently to the same experience in a way that favored the latter and prejudiced the former. The use of can reflects the ideologies of the context and takes on different meanings when referring to each group of people.

The second sentence, in turn, contrasts the present - 2019 was the year when the classes were planned - and the past. In “(In 2019) Can you play soccer?”, can means having the ability to play, because now soccer is a popular sport practiced by different people; it does not make sense to ask if one is allowed to play, unless we are talking about a child asking another if their parents give permission for them to go out and play. In this case, the meaning of can changes in relation to the time (commonsense ideas) when it is situated. The activity, therefore, highlights and encourages students to see that language is related to subject, time, and space. Depending on the class, students might need more sentences and more questions to perceive what is being problematized. It is important, however, that they understand it by analyzing the language rather than being told by the teacher.

Gender issues on playing soccer could also be worked on, for instance, the common association of the sport with men. However, the didactic sequence has an objective that is defined to be fairly specific (as opposed to being too broad and addressing lots of issues at the same time). Given that the learning process is chaotic, rather than linear (MENEZES DE SOUZA, 2011a), can may be worked with again, from a different perspective, in another moment.

In this first class, as well as in the other two, there is a problematization of meritocracy, the neoliberalist idea which holds that anyone can achieve whatever they desire if they work hard, ignoring the barriers resultant of social, historical, and political processes (MILNER, 2010). In Brazil, the color-blindness discourse, which is based on the premise of 'racial harmony', is very strong. Racism, in this sense, is not explicitly validated by the country, but it permeates discourses and actions (SCHUCMAN, 2014). As Wieviorka (2006 apud SCHUCMAN, 2014, p. 86, my translation) claims, “institutional racism appears as a set of mechanisms, not perceived socially and which 
allows keeping Black people in a position of inferiority [and privileging Whites], without the need to express racist prejudice, with no need for a racist policy to underpin exclusion or discrimination." 8 The myth of meritocracy ignores that these mechanisms exist and favor the White, defending that everything is earned based on merit.

In this class, therefore, can is relativized in the sense that minorities (here, specifically, considering race and social position) face difficulties to be able to do something that a person who belongs to privileged groups would not.

The second class starts with a warm-up called Word Association'. Students would have to say words or expressions related to can (first round) and can't (second round). This activity works as a means both to have students remembering discussions from the first class and to help them realize the associations they make. Next, they would fill in the blanks in two short personal reports, using the affirmative or negative form of can. This is a frequently used activity in English language classes, which mostly involves practicing a structure or checking listening comprehension (with songs, for instance). For this class, I have developed the task to demand critical thinking because, to complete the spaces, students have to consider historical context and the position the subject occupies.

\begin{abstract}
My name is Louis. I am 20 years old man living in 2019, and I work as the gatekeeper of a school downtown. I get a minimum wage, so I travel abroad very often. I also __ afford cutting-edge technology. In fact, sometimes, I _ afford all of the basic items, like food, clothes and pay the bills.

My name is Jack Johnson and I am the first Black heavyweight boxing champion and I box. In the beginning of this year, 1901, the White boxer Jim F. Jeffries refused to fight me; White boxers will not spar with their black counterparts, so I fight him or other boxers.
\end{abstract}

The first report is entirely fictional, that is, it was not based on a real specific story. I considered a financial situation many Brazilians face: living with a minimum wage

\footnotetext{
8 “o racismo institucional aparece como um conjunto de mecanismos, não percebido socialmente e que permite manter os negros em situação de inferioridade, sem que seja necessário que os preconceitos racistas se expressem, sem que seja necessário uma política racista para fundamentar a exclusão ou a discriminação" (WIEVIORKA, 2006 apud SCHUCMAN, 2014, p. 86).

${ }^{9}$ One person at a time says a word associated to the main category (can in the first round and can't in the second). If one takes longer than 15 seconds to answer or repeats a word someone has said, he or she is eliminated from the round. The last person remaining is the winner. If there are too many students in class, they can be grouped and, instead of saying a word for themselves, they do it for the group. The last group in the round wins.
} 
salary. The second one, in turn, is based on Jack Johnson's real story. The use of can or can't, in this case, is entirely related to social and racial issues. Students must consider how these matters can make being able to do something more difficult, which means it does not depend only on how much one fights to achieve a goal, there are barriers that will stand in the way. The effort here is to deconstruct the meritocratic discourse, which became commonsense. Menezes de Souza (2011b) argues that the Freirean concept of conscientização refers to attempting to understand the wor(1)d or texts in general upon which one acts, going beyond commonsense in a constant process of reflecting on and questioning our own readings.

After filling the blanks, students should discuss their answer with their classmates in groups of five people, highlighting the reasons for their choices. Students would listen to others and explain their reasoning; in the process, they might realize their own understandings. In this sense, as Menezes de Souza (2011b, p. 130, my translation) claims, based on Freire, "the perception of self as an 'I', Freire says, arises from the consciousness of a 'not-I' from which it emerges, detaches and to which the individualized 'I' connects. The sociohistorical 'not-I' is different from and constitutes the 'I' of the social identity."

For the next activity, students would use the drawings from the first class. They would place them, using tape, on a table which presents different situations.

Table 1: activity from the second class

\begin{tabular}{l|l|l|l|}
$\begin{array}{l}\text { This person lives by } \\
\text { him/herself in a huge } \\
\text { apartment in } 2019 .\end{array}$ & $\begin{array}{l}\text { This person - from } \\
2019-\text { is unemployed } \\
\text { and living with his/her } \\
\text { They also own around } \\
\begin{array}{l}200 \text { million dollars } \\
\text { and a company. }\end{array}\end{array}$ & $\begin{array}{l}\text { This person works for a } \\
\text { minimum wage in a } \\
\text { struggling to find a job. } \\
\text { lives alone in a small } \\
\text { house. }\end{array}$ & $\begin{array}{l}\text { This person lives in } \\
\text { small house in a } \\
\text { senement with his/her } \\
\text { family. }\end{array}$ \\
\hline
\end{tabular}

Source: The author (2020). 
Once again, students would be able to see their associations, becoming aware of who they associate with each socioeconomic position. The idea of working with racism and social inequality comes from the need to problematize the relation between them in Brazil. Pereira and Lacerda (2019, p.103, my translation) conclude, after analyzing narratives that

returning to the question this paper proposes, namely: to which extent do social and economic inequalities interfere in the formation of Black identities? The conclusion is that these categories decisively interfere in the construction of identities, which can be confirmed by the narratives presented, where the condition of socioeconomic poverty and vulnerability have modeled my family and personal identity, making my independent spontaneous and conscious action, as a person and as a citizen, difficult. Only in the beginning of my adult life, given the diverse situations presented [in the narratives], it was possible to understand the whole dynamic of the constitution of my identity and, therefore, look for ways to overcome the chains which held me back. Therefore, I understand that my story happens repeatedly with many Blacks in our country. Being Black in Brazil means being poor, disbelieved, and silenced. The silencing is the product of the action of White identity hegemonic discourse which, by being massively repeated, becomes true ${ }^{10}$ (PEREIRA; LACERDA, 2019, p. 103, my translation).

They propose, however, that this discourse can be interrupted. From the critical literacy perspective, one needs to become aware of the commonsense ideologies from which he or she is constructing meaning in order to overcome them. For this reason, in the classes analyzed in this paper, there is a repeated effort to have students perceiving their own readings.

After putting their drawings on the table, students had to get together in groups of five people and pick one of the 'characters' they drew (and his or her short description) to write their personal report. The work of actually writing begins in the third and last class.

The class starts with a brainstorming activity. Students would write on the board

\footnotetext{
${ }^{10}$ Retomando à questão posta por esse trabalho, qual seja: em que medida as desigualdades sociais e econômicas interferem na formação das identidades negras ¿ percebeu-se que essas categorias interferem de forma decisiva na construção das identidades, o que pode ser confirmado pelas narrativas apresentadas, onde a condição de pobreza e vulnerabilidade social e econômica modelou a minha identidade familiar e pessoal, dificultando minha atuação de forma independente, espontânea e consciente com pessoa e como cidadã, até o início de minha vida adulta, onde somente por conta das diversas situações apresentadas, foi possível entender toda a dinâmica de constituição de minha identidade e assim buscar superar as amarras que me prendiam, assim, entendo que minha história se repete e confunde com as diversas histórias de negros e negras em nosso país. Ser negro no Brasil significa ser pobre, desacreditado e silenciado. O silenciamento é o produto da ação do discurso hegemônico da identidade branca, que ao ser massivamente repetido, passa a ser verdadeiro (PEREIRA; LACERDA, 2019, p. 103).
} 
actions related to can, that is, things which one has the ability or would need permission to do, possibilities or requests. Then, in groups, they would elaborate sentences expressing activities their character, considering his or her context, would be able to do or not (given social, economic, historical, and racial barriers). The next step is to put the sentences together in a personal report of a day in their character's life. In the planning process, I considered the possibility of students writing personal reports about themselves, but there are some issues related to this decision. First, there is the emotional factor. They could feel uncomfortable to talk to their classmates about the issues they face, and the activity could end up exposing Black students. As Milner (2008, p. 338-339, his emphasis) explains:

students of color are sometimes recruited to be the "spokesperson" for their race; for example, during class discussions, they are asked to address every issue facing Asian Americans in education, and what I have observed is that this strain can cause students of color to retreat and withdraw from the teaching and learning exchange because they cannot and, more important, should not be asked to speak on behalf of their race (or ethnic background) on all, or even most, issues (MILNER, 2008, p.338-339, his emphasis).

In addition to that, I have considered the possibility of students having similar socioeconomic backgrounds. In this case, the differences would not be so visible. By having millionaires as well as unemployed people, for example, the contrast is more evident. For these reasons, I chose to work with fictional characters.

\section{FURTHER CONSIDERATIONS}

In this paper, I analyzed the process of planning classes from the critical literacy perspective. In order to work with this theory, regardless of the things we want students to do and to reflect on, we have to consider our own readings on the topic. The goal is not and must not be to make students think like we do, but rather to have them acknowledging how they make sense of the world through ideologies constructed and reverberated socially. For this reason, they should experience activities that make them realize their own readings, so they may deconstruct them.

Understanding that the ideologies that permeate one's readings are reinforced repeatedly as the natural ways to understand texts throughout a person's life, the work 
with critical literacy cannot take place in only one moment of a class; it has to be constant, so students can get used to the practice of reading and questioning themselves. This is why, in the didactic sequence, all of the activities are developed under the theory's perspective.

In addition, I emphasize that language and a critical approach should not be dissociated. If, for example, a teacher works with grammar and explains how one should use can and, in a different moment of the class, discusses an issue such as social inequality, he or she might reinforce the idea that language is neutral, separated from social issues. In the analyzed classes, can is worked as inseparable from ideologies, so students might see that language is always ideological and related to a subject's position, to time and to space.

In accordance with Janks' claim (2012, p. 153), I highlight that deconstruction, that is, "critique is not the end-point; transformative and ethical re-construction and social action are." In this sense, our own readings have a direct impact on the social, given that our actions are informed by our ideologies.

Finally, within the Education field, White privilege is noticeable, especially when we consider the number of White teachers/professors in comparison with the number of Black ones. An antiracism movement requires that we, Whites, acknowledge our own privileges and understand that, by ignoring racism, we reinforce it. When it comes to planning classes, constantly asking ourselves about the ideologies our practice is reverberating is essential if we aim to contribute to social justice. I agree with Schucman (2014) when she says that we, White people, need to acknowledge our raciality and see ourselves as promoters of changes in our own contexts. The modifications, nonetheless, besides individual, have also to be structural.

\section{REFERENCES}

AGA. G.; MARTÍNEZ, V. Time to share - 6º ano. São Paulo: Editora Saraiva, 1 ed., 2015.

BARCELOS, A. M. F. Lugares (im)possíveis de se aprender inglês no Brasil: crenças sobre aprendizagem de inglês em uma narrativa. In: LIMA, D. C. de (org.). Inglês em escolas públicas não funciona? São Paulo: Parábola, 2011, p. 147-158. 
BEZERRA, S. S. Letramentos em questão: um resgate histórico. Linguagem em Foco, Fortaleza, v. 9, n. 1, p. 131-139, 2017.

BEZERRA, S. S. Reflexões sobre colonialidade de gênero e letramento crítico em aulas no ensino médio. Rev. Bras. Linguíst. Apl., Belo Horizonte, v. 19, n. 4, p. 901-926, 2019.

BOA SORTE, P.; SILVA, N. S. M. English teaching conceptions: cognitive processes on ongoing professional development. Revista COCAR, Belém, v. 12, n. 24, p. 03-24, jul./dez., 2018.

COPE, B.; KALANTZIS, M. "Multiliteracies": New Literacies, New Learning. Pedagogies: An International Journal, [S.l.], v. 4, n. 3, p. 164-195, 2009.

FERREIRA, A. de J. Teoria racial crítica e letramento racial crítico: narrativas e contranarrativas de identidade racial de professores de línguas. Revista da ABPN, [S.l.] v. 6, n. 14, p. 236-263, jul./out., 2014.

FOUCAULT, M. Arqueologia do saber. Tradução de Luiz Felipe Baeta Neves, 7. ed. Rio de Janeiro: Forense Universitária, [1969] 2008.

FREIRE, P. Pedagogia do Oprimido. Rio de Janeiro: Paz e Terra, [1987] 1994.

GEE, J. Situated Language and Learning: A Critique of Traditional Schooling. New York: Routledge, 2004.

JANKS, H. The importance of critical literacy. English Teaching: Practice and Critique, [S.l.], v. 11, n. 1, p. 150-163, 2012.

JANKS, H. Doing critical literacy: texts and activities for students and teachers. New York: Routledge, 2014.

JORDÃO, C. M. Epistemofagia transformadora: saberes locais e inclusão no ensino superior brasileiro. Educação em Revista, Belo Horizonte, v. 27, n. 02, p. 249-276, ago., 2011.

JORDÃO, C. M. Abordagem comunicativa, pedagogia crítica e letramento crítico farinhas do mesmo saco? In: Rocha, C. H.; Maciel, R. F. (org.) Lingua estrangeira e formação cidadã: por entre discursos e práticas. Campinas, SP: Pontes Editores, 2013, p.69-90.

JUCÁ, L. Ensinando Inglês na Escola Regular: a escolha dos caminhos a seguir depende de onde se quer chegar. In: JESUS, D. M.; CARBONIERI, D. (org.). Práticas de multiletramentos e letramento crítico: outros sentidos para a sala de aula de línguas. Campinas: Pontes, 2016, p. 99-119.

LARSEN-FREEMAN, D. Techniques and Principles in Language Teaching. 2.ed. Oxford: Oxford University Press, 2003. 
LIMA, D. C. Vozes da (re)conquista: o papel da cultura no ensino da língua inglesa. Polifonia (UFMT), Cuiabá, v. 15, p. 87-107, 2008.

LÓPEZ-GOPAR, M. E.; SUGHRUA, W. Social Class in English Language Education in Oaxaca, Mexico. Journal of Language, Identity and Education, [S.l.], v. 13, n. 2, p. 104110, 2014.

MENEZES DE SOUZA, L. M. T. Remapping Writing: indigenous writing and cultural conflict in Brazil. English Studies in Canada, Ontario, v. 30, n. 3, p. 4-16, 2004.

MENEZES DE SOUZA, L. M. T. O Professor de Inglês e os Letramentos no século XXI: métodos ou ética? In: JORDÃO, C. M.; MARTINEZ, J. Z; HALU, R. C. (org.). Formação (Des) formatada: práticas com professores de língua inglesa. São Paulo: Pontes, 2011a, p.279-303.

MENEZES DE SOUZA, L. M. T. Para uma redefinição de Letramento Crítico: conflito e produção de significado. In: MACIEL, R. F.; ARAÚJO, V. A. (org.). Formação de professores de línguas: ampliando perspectivas. Jundiaí: Paco Editorial, 2011b, p.128-140.

MILNER, H. R. Critical race theory and interest convergence as analytic tools in teacher education policies and practices. Journal of Teacher Education, [S.l.], v. 59, n. 4, p. 332346, 2008.

MILNER, H. R. What does teacher education have to do with teaching? Implications for diversity studies. Journal of Teacher Education, [S.l.], v. 61, n. 1-2, p. 118-131, 2010.

MONTE MÓR, W. Critical literacies, meaning making and new epistemological perspectives. Revista Electrónica Matices en Lenguas Extranjeras, Bogotá, n. 2, p. 1-18, 2008 .

NASCIMENTO, G. Racism in English Language Teaching? Autobiographical Narratives of Black English Language Teachers in Brazil. Rev. Bras. Linguíst. Apl., Belo Horizonte, v. 19, n. 4, p. 959-984, 2019.

PEREIRA, A. L.; LACERDA, S. S. P. de. Letramento racial crítico: uma narrativa autobiográfica. Travessias, Cascavel, v. 13, n. 3, p. 90-106, set./dez., 2019.

SAVIANI, D. As Concepções Pedagógicas na História da Educação Brasileira, Projeto 20 anos do HISTEDBR, [S.l.], p. 01-35, 2005.

SCHUCMAN, L. V. Sim, nós somos racistas: estudo psicossocial da branquitude paulistana. Psicologia \& Sociedade, [S.l.], v. 26, n. 1, p. 83-94, 2014.

Recebido em: 21 jun. 2020.

Aceito em: 24 jul. 2020. 